\title{
Brown rot blossom blight of pome and stone fruits: symptom, disease cycle, host resistance, and biological control
}

\author{
Holb, I. J. \\ University of Debrecen, Centre of Agricultural Sciences, P. O Box 36. H- 4015 Debrecen, Hungary
}

\begin{abstract}
Summary: In this paper, important features of symptoms, biology and biological disease management are summarised for brown rot blossom blight fungi of pome and stone fruit crops (Monilinia laxa, Monilinia fructicola and Monilinia mali). Firstly, European brown rot caused by Monilinia laxa is discussed highlighting the blossom epidemiology features, then host susceptibility of the most important stone fruit species including several Hungarian and international cultivars. At the end of this chapter, recent biological control possibilities against Monilinia laxa are also included. Secondly, American brown rot caused by Monilinia fructicola is discussed. Symptoms, biological features of blossom blight and host susceptibility of flowers to Monilinia fructicola are demonstrated. Finally, the symptoms and the biology of the least frequent species, Monilinia mali are shown.
\end{abstract}

Key words: biological control, brown rot, blossom blight, epidemiology, host susceptibility, Monilinia spp., Monilinia laxa, Monilinia fructicola, Monilinia mali

\section{Introduction}

There are three main brown rot species in the world causing brown rot blossom blight of pome and/or stone fruit species. These species are Monilinia laxa, Monilinia fructicola and Monilinia mali. This overview was aimed to show the host range, symptoms, biology and the possible biological control of these pathogens on blossom in the following three chapters. The most commonly known brown rot blossom blight species are Monilinia laxa and Monilinia fructicola occurring almost worldwide causing severe blossom blight in Europe and the American continent, respectively. The third species mainly occurs in the northern regions of East Asia, mainly in Japan (Byrde \& Willetts, 1977).

\section{European brown rot}

The disease is also known as 'monilinia blossom blight', 'brown rot blossom blight', and 'apricot brown rot' (Rudolph, 1925). The blossom blight occurs mainly on stone fruits (Weaver, 1950), such as cherry (Wilcox, 1989; Tamm et al., 1995), plum (Schlagbauer \& Holz, 1990), peach (Sutton \& Clayton, 1972), nectarine (Ogawa et al., 1980), apricot and almond (Mix, 1930), however, it can also be present on apple (Sharma \& Kaul, 1987), pear and quince (Holb, 2003). Apricot is the most susceptible to blossom blight, followed in order by prune, sweet cherry, peach, sour cherry and plum.
The disease is caused by an ascomycete fungus, Monilinia laxa (Aderh. \& Ruhl.) Honey (=Sclerotinia laxa Aderh. \& Ruhl.).

\section{Symptoms}

The principal feature of European brown rot is severe blossom and twig blight. Blossom blight is the first symptom in spring. Blossom infection appears when macroconidia or ascospores land on and penetrate flowers of susceptible plants. The critical period for blossom infection extends from the time the unopened flowers emerge from the winter buds until the petals are shed. All parts of the flower can serve as a first infection site. There is evidence that the fully open flowers are the most susceptible to infection. However, this can be different depending on fruit species. Calavan \& Keitt (1948) reported that the most frequent sites of infection in cherry blossoms are the anthers, stigmas, and petals. In almond, stigma infection is the most common, with anthers and petals as the next most frequently infected parts (Ogawa \& McCain, 1960). On apricot, plum and prune, all blossom parts are susceptible. The first symptoms are brown lesions on petals, stamens and pistils. If the weather is humid, the infected parts are softened and rotten. In a dry atmosphere, they are discoloured, dry and brittle. The discolouration may extend along the peduncle and to the young fruit (Byrde \& Willetts, 1977). After penetration, mycelium may invade the petals and stamens entirely in a period of 48 hours and spread into the calyx (Weaver, 1950). Later, the fungi may reach the tissue of the spur and consequently, attack other flowers in 


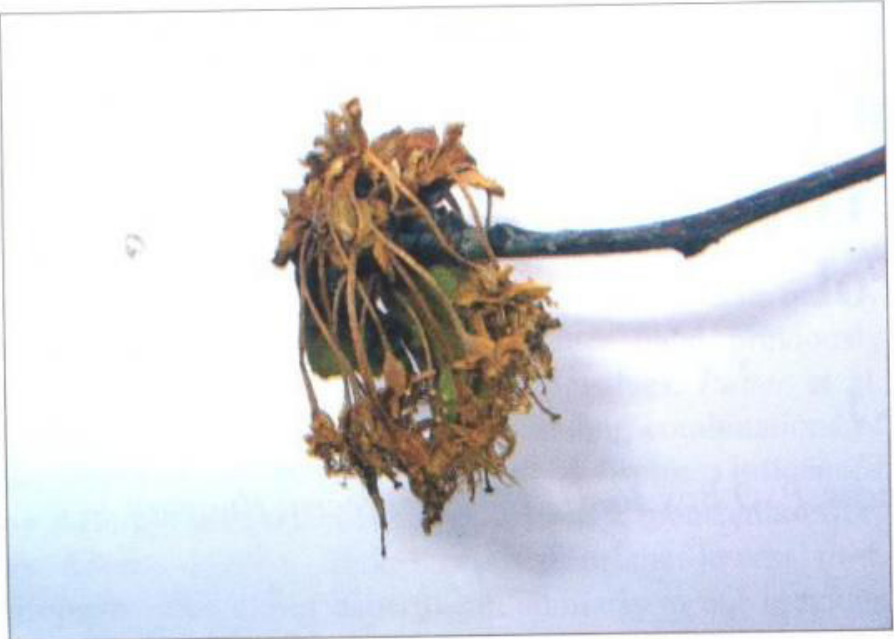

Figure 1 Brown rot blossom blight on sour cherry (cv. Érdi Bötermō) Photo by I. J. Holb

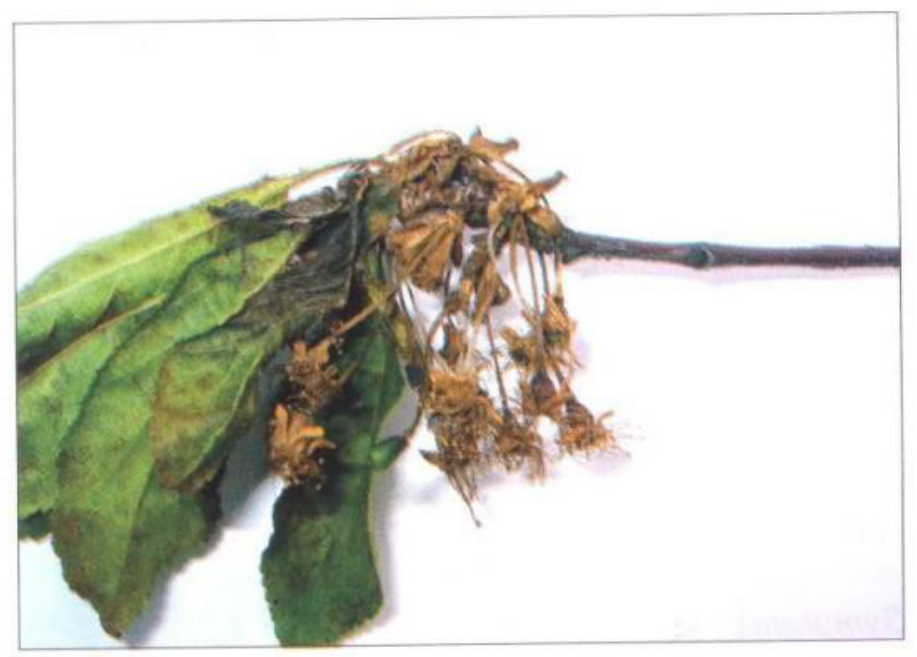

Figure 2 Brown rot blossom blight coupled with leaf blight on sour cherry (cv. Ujfehértói fürtös) Photo by I. J. Holb

the cluster. Some infected blossoms fall to the ground, but others can remain attached to the tree for long periods and these typical symptoms give a blighting appearance to the infected plant parts (Figure I). The blossom blight causes reduction in the fruit set and also infection of young fruits, therefore, it decreases the yield (Zehr, 1985; Batra, 1991). A secondary effect of blossom blight is twig infection (Figures 2 and 3). When the blossom is infected, the fungus grows from the floral parts through the peduncle into the twigs and as a consequence, new sources of inoculum are created for future infection. On peduncles, sporulation usually occurs on the fruit abscission surface. Ogawa et al. (1980) noted that blossom infection causes twig blight and partial girdling of the twigs on peach and nectarine. Twig infections may also result from infected cankers and blighted leaf tissue. On blighted twigs sporulation normally appears on abscission scars of leaves and bud scales on the basal section of the twig. About 10 days after infection, a gummy exudate may appear on the twig at the base of the diseased blossoms (Weaver, 1950). Ogawa et al. (1980) observed that profuse gumming occurs with extensive twig blight on apricot and plum. The infected twig is usually killed by the

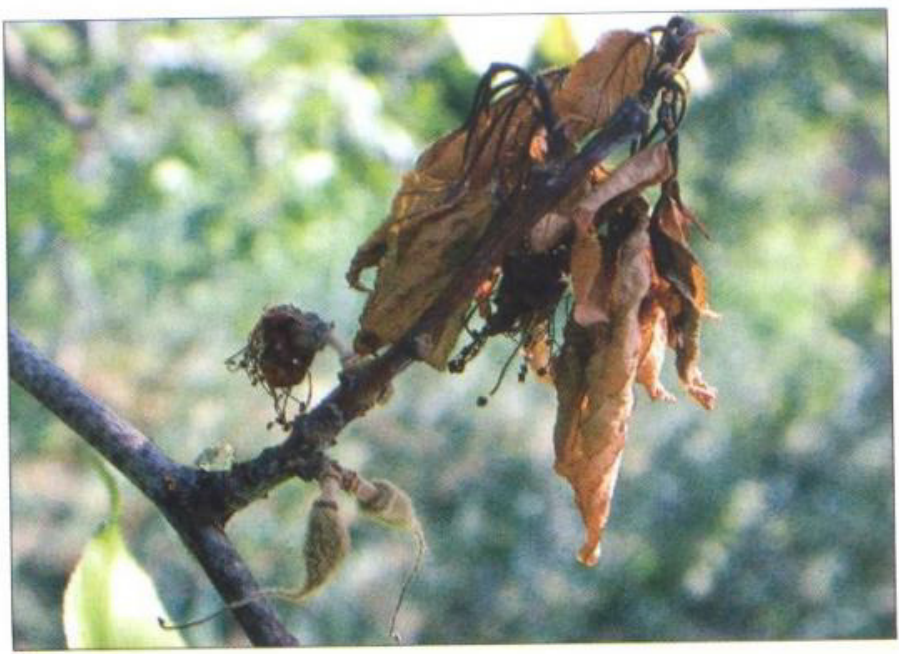

Figure 3 Brown rot blossom and twig blight on apricot (cv. Bergeron) Photo by I. J. Holb

invasion of the fungus, however, Mirocha \& Wilson (1961) showed that the infected twig probably dies from a toxin.

\section{Disease cycle}

M. laxa survives from one season to the next in twig cankers, blighted blossoms, peduncles, and in the rotted, mummified fruits hanging in the tree. Conidia begin to develop on these parts in spring. The production of $M$. laxa conidia from mummified fruits, blighted spurs and flowers were thoroughly studied on sweet cherry (Stensvand et al., 2001). Large numbers of conidia are produced on mummified cherry fruits left hanging on the trees for 2-3 years after infection. The production of conidia from overwintered fruit mummies was more than 10 times higher compared to the conidial production from an overwintered fruit spur or newly infected flower. The highest sporulation on mummified fruits and fruit spurs occurs prior to flowering, and very few conidia are produced at harvest. Flowers infected in the spring produce most conidia during the first two months after infection. The newly infected flowers produce more than 10 times more conidia than infected, overwintered flowers in the following spring. Consequently, an abundant and timely supply of inoculum is strategically located in the tree when blossoms emerge in the spring (Stensvand et al., 2001).

The conidia are blown about by wind (Corbin \& Ogawa, 1974; Corbin et al., 1968; Wilson \& Baker, 1946) and washed about by rain (Corbin et al., 1968). When they lodge on susceptible tissue, they germinate in two to four hours if moisture is present and temperature is favourable. A high percentage of newly formed conidia are germinable, and if not exposed to direct sunlight and high temperature, they retain their viability for months (Corbin et al., 1968; Corbin \& Ogawa, 1974).

At ordinary springtime temperatures, three to six days elapse between blossom infection and the first evidence of necrosis. This is followed by rapid necrosis of the entire blossom. Infection and development of disease symptoms occur over a relatively wide temperature range between 4 
and $30^{\circ} \mathrm{C}$, the optimum being about $24^{\circ} \mathrm{C}$ (Calavan \& Keitt, 1948). Low-moisture conditions limit infection; little or no infection occurs in rainless weather, even if humidity is high (Weaver, 1943). During the season, several successive cycles of secondary infection can occur on fruits particularly near fruit maturing and mummified fruits are formed. Finally, blighted blossoms, peduncles, twig cankers, and mummified fruits can serve as a survival structure for the fungus.

\section{Host resistance}

There are several reports on susceptibility and resistance of fruit cultivars to European brown rot blossom blight, which knowledge are used to increase efficacy of disease management (Paszternák et al., 1982; Holb, 2004a; Holb \& Schnabel, 2005ab) (Table l). There are some sour cherry cultivars with low susceptibility or disease tolerance, such as 'Lativiszkaja Nizkaja', 'Nagy Angol', 'Mocanesti', 'Ljubszkaja', 'Sirpotreb', 'Oblacsinszkaja', 'Cigánymeggy 3', 'Maraska Savena', 'Mettar' and 'Elegija' (Soltész, 1997). Moreover, Apostol (1990), Apostol \& Véghelyi (1992) and Véghelyi et al. (1996) revealed that 'Csengôdi', 'Akasztói' and 'Cigánymeggy 59' cultivars of sour cherry were partly resistant to $M$. laxa. Among almond cultivars, Drake and Jordanolo are highly susceptible and 'Ne Plus Ultra', 'Mission', 'Nonpareil', 'Peerless', and 'Davey' are moderately susceptible to blossom infection (Ogawa et al., 1985, 1986). 'Royal', 'Blenheim', 'Perfection', and 'Derby Royal' cultivars of apricot are highly susceptible to blossom infection, whereas 'Tilton' is less susceptible (Hesse, 1938). Recently, Szabó (1997) classified several apricot cultivars into brown rot susceptibility groups. He evaluated that cvs. 'Budapest' and 'Mandulakajszi' are highly, 'Ceglédi óriás', 'Liget óriás' and 'Polonais' are moderately and 'Borsi-féle kései rózsa', 'Piroska', 'Pannónia', 'Ceglédi bíborkajszi', 'Magyar kajszi' and 'Rakovszky' are lowly susceptible to blossom and twig blights caused by M. laxa. In the United States, 'Santa Rosa' and 'Wickson' plums and
'Imperial','Italian' and 'French' prunes cultivars are susceptible to blossom blight (Ogawa \& English, 1991).

\section{Biological control}

Possibilities of biological control are under continuous investigation in order to gain effective bioproducts against M. laxa. In 1980 and 1981, microflora of peach twigs and flowers was assessed and the most frequent genera were Penicillium, Alternaria, Aspergillus and Cladosporium spp. (Melgarejo et al., 1985). The authors found that five species (Aspergillus flavus, Epicoccum nigrum, Penicillium chrysogenum, $P$. frequentans and $P$. purpurogenum) inhibited the growth of $M$. laxa. These substances were apparently active against spore germination and hyphal growth. In a similar work, Melgarejo et al. (1986) studied the potential of $A$. flavus, $E$. nigrum, $P$. frequentans and $P$. purpurogenum for the biocontrol of $M$. laxa. The experiments were conducted in spring and early autumn in the field in Spain (Zaragoza). In spring, E. nigrum, $P$. frequentans and $P$. purpurogenum significantly reduced infection when introduced before inoculation with the pathogen. However, in autumn, only the treatments with $E$. nigrum resulted in a reduction of the $M$. laxa infection. De Cal et al. (1988) showed that $P$. frequentans produces antifungal compounds that are active against $M$. laxa: This production started after 10 days of incubation of $P$. frequentans in potato dextrose broth, and continued for approximately 20 days, when inhibition reached a maximum. De Cal et al. (1990) tested the antagonist P. frequentans alone or in alternation with captan in the field in order to control peach twig blight. Preparation of the antagonist with nutrients gave significant reductions in the severity of disease. Combination of the antagonist with captan resulted in similar control as that provided by the antagonist or captan alone. Madrigal et al. (1991) made a similar study with E. nigrum on peach tree and they found that the control effect of the antagonist on the disease was variable. The most

Table 1 Examples of resistant and susceptible fruit cultivars to brown rot caused by Monilinia spp.

\begin{tabular}{|l|l|l|l|l|}
\hline Fruit & \multicolumn{1}{|c|}{ Host resistance } & \multicolumn{1}{|c|}{ Plant organ } & \multicolumn{1}{|c|}{ Cultivar } & \multicolumn{1}{c|}{ Reference } \\
\hline almond & high susceptibility & blossom, twig & Drake, Jordanolo & Ogawa et al., 1985, 1986 \\
\hline almond & moderate susceptibility & blossom, twig & Ne Plus Ultra, Texas & Ogawa et al., 1985, 1986 \\
\hline apricot & tolerant & blossom, twig & Neptun, Mamaia, Silvana, Sulina, Sirena & Cociu cit. Soltész, 1997 \\
\hline apricot & high susceptibility & blossom, twig & Budapest, Mandulakajszi & Szabó, 1997a \\
\hline apricot & moderate susceptibility & blossom, twig & Ceglédi óriás, Liget óriás, Polonais & Szabó, 1997a \\
\hline apricot & low susceptibility & blossom, twig & $\begin{array}{l}\text { Borsi-féle kései rózsa, Piroska, Pannónia, } \\
\text { Ceglédi bíborkajszi, Magyar kajszi, Rakovszky }\end{array}$ & Szabó, 1997a \\
\hline $\begin{array}{l}\text { peach } \\
\text { plum }\end{array}$ & high susceptibility & blossom & Bolinha & $\begin{array}{l}\text { Feliciano et al., 1987; } \\
\text { Ogawa \& English, 1991 }\end{array}$ \\
\hline $\begin{array}{l}\text { sour } \\
\text { cherry }\end{array}$ & partial resistance & blossom, twig & Canta Rosa, Wickson, Imperial, French & Ogawa \& English, 1991 \\
\hline $\begin{array}{l}\text { sour } \\
\text { cherry }\end{array}$ & low susceptibility & blossom, twig & $\begin{array}{l}\text { Lativiszkaja Nizkaja, Nagy Angol, Mocanesti, } \\
\text { Ljubszkaja, Sirpotreb, Oblacsinszkaja, } \\
\text { Cigánymeggy 3, Maraska Savena, Mettar, Elegija }\end{array}$ & $\begin{array}{l}\text { Apostol, 1990; Apostol \& } \\
\text { Véghelyi, 1992; Véghelyi et al., 19996 }\end{array}$ \\
\hline
\end{tabular}


successful treatment was when E. nigrum was used in combination with captan. Further examination of E. nigrum showed that the fungus produced an antifungal compound, flavipin, which was toxic to M. laxa. Madrigal \& Melgarejo (1994) applied this compound to spores of M. laxa and the level of ATP in the brown rot fungus cells dropped suddenly, which indicated that there was a strong inhibition in the respiration process. Flavipin seemed to affect also the protein synthesis but the mode of action of the compound has not been determined yet. The lytic enzyme producing fungus, $P$. purpurogenum was also tested against $M$. laxa. Crude filtrates and crude enzyme preparations of the antagonist cultures produced lysis of the hyphae and spores of $M$. laxa (Larena \& Melgarejo, 1996). Pascual et al. (1999, 2000) investigated the production of $E$. nigrum by substrate fermentation and the accumulation of compatible solutions in P. frequentans. De Cal et al. (2002) achieved mass conidial production of $P$. frequentans and Larena et al. (2003) dried E. nigrum conidia for obtaining self-stable biological products against $M$. laxa.

\section{American brown rot}

The disease is also known as 'fruit brown rot', and 'peach brown rot'. M. fructicola has more hosts in the Prunoideae than in the Pomoideae. In the first sub-family are included peach (Prunus persica (L.) Batsch), apricot ( $P$. armeniaca L.), plum ( $P$. domestica L.), sweet cherry $(P$. avium L.), sour cherry $(P$. cerasus L.) and almond $(P$. dulcis L.). In Pomoideae, it attacks quince (Cydonia oblonga Mill.), apple (Malus domestica Borkh.) and pear (Pyrus communis L.) It may also appear in grapes (Vitis vinifera L.). The disease is caused by an ascomycete fungus, Monilinia fructicola (Wint.) Honey (=Sclerotinia fructicola (Wint.) Rehm) (Byrde \& Willetts, 1977).

\section{Symptoms}

M. fructicola causes brown rot on ripening fruits of Prunus species and not so often in pome fruits. However, it is also an important pathogen causing blossom and twig blight and cankers on several fruit hosts (Batra, 1991). Symptoms are very similar to those described for European brown rot. The most important difference is that the mycelium of $M$. fructicola could remain dormant or quiescent on young fruits until the beginning of fruit maturity and then the fruit becomes infected (Batra, 1991; Willetts \& Burllock, 1993).

\section{Disease cycle}

The fungus survives the winter in several ways: A) As mummified fruits hanging in the tree; here conidia are produced on the surface of the fruit in spring. B) As mummified fruits on the ground; on such fruit the fungus produces the typical pseudosclerotial mat (stroma) from which the apothecia arise. Apothecia are never produced from nonstromatized or recently-infected (fleshy) fruit (Holtz et al., 1998). The apothecia appear and mature at the time the host blossoms in the spring. They discharge their spores into the air for a few weeks and then disintegrate. C) As mycelium in blossom parts, peduncles, and twigs killed by the pathogen the previous year (Sutton \& Clayton, 1972). Sporulation on peduncles, twigs and branch cankers occurs frequently in the eastern United States and Australia (Kable, 1965 b) but is less common in California. Sources of inoculum for South Carolina peach orchards were found to be nonabscised aborted fruit, infected thinned fruit on the ground, and infected fruit on wild plum trees (Landgraf \& Zehr, 1982).

In spring, apothecia may develop from the overwintered pseudosclerotial mat (stroma) when the asci are mature and conditions are favourable, the ascospores are discharged causing the primary infection. Apothecia develop in areas where the soil is moist in the spring. Ascospores are forcibly ejected into the air and are carried by air currents about the orchard. Slight disturbances in the air (which change the humidity) initiate ascospore discharge. The liberation of ascospores normally coincides with the emergence of young shoots and blossoms of plants. The primary cycle can also begin with the conidia formed on mummified fruits on the tree and on other infected host tissues (twig cancers and blighted flowers that remain in the tree). Conidia are freely disseminated by moving air, rainwater (Jenkins, 1968; Kable, 1965a), and insects (Tate \& Ogawa, 1975). Conidia produced on mummified fruits may also survive the winter and cause infection in spring (Bertram, 1916). These are formed at the end of the season, possess a thicker wall, and are more resistant than those produced during the early summer. However, it is generally accepted that peduncles and fruit mummies producing new pustules provide the major inoculum sources. Mycelia in buds and leaves do not seem to contribute to a great extent to primary infections (Byrde \& Willetts, 1977).

Ascospores or conidia produced from mummies cause blossom blight in the spring under favourable conditions (Byrde \& Willetts, 1977; Kable, 1965b; Sholberg et al., 1981; Landgraf \& Zehr, 1982). After infection, initial hyphae colonise infected floral parts, then the mycelium pushes outward through the epidermis, and forms numerous conidial tufts on the infected tissues. In the meantime, the mycelium rapidly grows on the tissues of blossom petioles and from there into the fruit spurs and the twigs. In the twig, a reddishbrown shield-shaped canker forms. Infected twigs often become girdled and die. Primary infections of blossom can also function as a source of latent infection of fruit (Jerome, 1958; Jenkins \& Reinganum, 1965; Tate \& Corbin, 1978; Gubler et al., 1987; Cruickshank \& Wade, 1992; Wade \& Cruickshank, 1992). When microclimatic conditions are unfavourable, these primary infections can remain latent until conditions are favourable for disease development that leads to fruit rot. The level of latent infection in fruit is influenced by both primary and secondary infections (Wade, 
1956; Wade \& Cruickshank, 1992; Luo et al. 2001). The latent infection could occur over the whole season under favourable conditions.

Blossom blight may cause severe yield losses on stone fruit by reducing the number of flowers and twigs. Moreover, infected flowers and twigs with sporulation serve as a source of secondary inoculum for infection of fruit (Sholberg et al., 1981; Landgraf \& Zehr, 1982). However, e.g. in California, the main inoculum sources for secondary infection are conidia produced on the thinned infected fruits on the orchard floor (Hong et al., 1997).

A few green fruits may become rotten in early summer. This is thought to result mainly from quiescent (incipient) infections (Tilford, 1936) or insect wounds (Tate \& Ogawa, 1975), because direct infections require over 30 hours of continuous moisture. However, Biggs \& Northover (1988) have shown that young peach fruits are highly susceptible to infection, then the fruits become resistant at pit hardening, and later they become increasingly susceptible at two to three weeks before full ripeness. Although the injury of the fruit may lead to an increase in infection, the fungus readily infects when no wound or fruit-to-fruit contact is present (Michailides \& Morgan, 1997). It commonly enters the fruit by the way of trichome (hair) sockets. Rains and accompanying high humidity favour infection. Thus, the disease occurs most frequently and causes the greatest destruction in the more humid fruit-growing areas (Sonoda et al., 1983); nevertheless, the disease may also appear during a rainless period. Dew at night probably provides the moisture for spore germination and infection. Fruit infection is most common during the last few weeks before harvest. Infected fruits sprorulate and increase the secondary inoculum. There are several successive cycles of secondary infection on different plant parts. Finally, the fungus can survive on twig cankers, blighted blossoms, peduncles, and mummified fruits, as we described earlier.

\section{Host resistance}

No peach cultivar has been known to be highly resistant to blossom brown rot caused by $M$. fructicola. The peach cultivars Dixon, Fortuna, Vivian, and Walton show more blossom blight than do Halford and Stuart. Only cv. 'Bolinha' showed moderate resistance to American brown rot (Feliciano, et al., 1987).

There is no available information about the biological control possibilities against blossom blight caused by Monilinia fructicola.

\section{Monilia leaf blight}

Monilia leaf blight (Monilinia mali (Takahashi) Whetzel) is an important disease of apple and of wild species of Malus spp. in the northern regions of East Asia. In Japan, it occurs primarily in Hokkaido and northern Honshu, where losses from the disease date back to the 1890 s, soon after domestic apples were first grown in Japan. The distribution of the disease in these countries is limited to regions with heavy winter snows and long, cool springs (Kimura, 1962; Harada, 1977).

\section{Symptoms}

Infected young leaves develop small, brown spots. The lesions expand rapidly, and result in collapse of the leaves. Usually leaves wilt and grayish patches of fungus form on the lower surface of infected leaves. After severe outbreaks of leaf blight, flower clusters and fruiting spurs are killed. Blossoms are killed from mycelium originating in diseased leaves, not from the stigma, pistil or petals downward. Blighting also occurs when mycelium moves into the healthy leaves and blossoms (Kimura, 1962; Harada, 1977).

\section{Disease cycle}

In the field, pseudosclerotia germinate in mummies and initials of apothecia form beginning in late autumn (October in Japan). Eventually, the development of apothecial initials is supressed by low temperatures under the snow. They grow again after the snow melts in early spring. Apothecia develop rapidly and produce the largest amount of ascospores during tree flowering (Willetts \& Harada, 1984). Ascospores are ejected from apothecia by air currents. The ascospores are wind-transported and infection starts when spores land on lower surface of apple leaves. Leaves on spurs are attacked more often than leaves on terminal shoots. Gray fascicles with conidia are formed on the lower surface of infected leaves, but the conidia do not initiate secondary infection on leaves. Young fruit can be infected by both conidia and ascospores from late-developing apothecia. After infection, young fruits quickly rot and then the fungus grows through the stem of the fruit and into the spur, which is often killed. Pseudsclerotia form within fallen rotten fruit during summer (Harada, 1977).

There is no available information about the host resistance and biological control possibilities of Monilinia mali.

\section{Acknowledgements}

The study was partly supported by a János Bolyai Research Fellowship and the Hungarian Scientific Research Fund.

\section{Literature Cited}

Apostol, J. \& Véghelyi, K. (1992): Meggymonilia. Ígéretesen ellenálló fajták. Kertészet és Szôlészet. 41 (20): 8-9.

Apostol, J. (1990): Biomeggy. Kertészet és Szôlészet 39 (17): 3.

Batra, L.R. (1991): World species of Monilinia (Fungi): Their ecology, biosystematics and control. Mycologia Memoir No. 16, J. Cramer, Berlin, 246 pp. 
Bertram, H.E. (1916): A study of the brown rot fungus in northern Vermont. Phytopathology. 6: 71-78.

Biggs, A. R. \& Northover, J. (1988): Early and late-season susceptibility of peach fruits to Monilinia fructicola. Plant Disease. 72: 1070-1074.

Byrde, R.J.W. \& Willetts, H.J. (1977): The brown rot fungi of fruit. Their biology and control. Pergamon Press, Oxford, 171 pp.

Calavan, E. C. \& Keitt, G.W. (1948): Blossom and spur blight (Sclerotinia laxa) of sour cherry. Phytopathology. 38: 857-882.

Corbin, J.B. \& Ogawa, J.M. (1974): Springtime dispersal patterns of Monilinia laxa conidia in apricot, peach, prune, and almond trees. Canadian Journal of Botany. 52: 167-176.

Corbin, J.B., Ogawa, J.M. \& Schultz, H.B. (1968): Fluctuations in numbers of Monilinia laxa conidia in an apricot orchards during the 1966 season. Phytopathology. 58: 1387-1394.

Cruickshank, R.H. \& Wade, G.C. (1992): The activation of latent infections of Monilinia fructicola on apricots by volatiles from the ripening fruit. Journal of Phytopathology. 136: 107-112.

De Cal, A., Larena, I., Guijarro, B. \& Melgarejo, P. (2002): Mass production of conidia of Penicillium frequentans, a biocontrol agent against brown rot of stone fruits. Biocontrol Science and Technology. 12: 715-725.

De Cal, A., M-Sagasta, E. \& Melgarejo, P. (1988): Antifungal substances produced by Penicillium frequentans and their relationship to the biocontrol of Monilinia laxa. Phytopathology. 78: 888-893.

De Cal, A., M-Sagasta, E. \& Melgarejo, P. (1990): Biological control of peach twig blight (Monilinia laxa) with Penicillium frequentans. Plant Pathology. 39: 612-618.

Feliciano, A., Feliciano, A.J. \& Ogawa, J.M. (1987): Monilinia fructicola resistance in peach cultivar Bolinha. Phytopathology. 77: 776-780.

Gubler, W.D., Manji, B.T., Ogawa, J.M. Yoshikawa, F. (1987): Quiscent infection of M. fructicola on Fair plum. Proceedings of 61st Annual Western Orchard Pest and Disease Management Conference: 2 .

Harada, Y. (1977): Studies on the Japanese species of Monilinia (Sclerotiniaeae). Fac. Agric. Hirosaki Univ. Bull. 27: 30-109.

Hesse, C.O. (1938): Variation in resistance to brown-rot in apricot varieties and seedling progenies. Proceedings of the American Society for Horticultural Science. 36: 266-268.

Holb I.J. (2003): The brown rot fungi of fruit crops (Monilinia spp.) I. Important features of their biology (Review paper). International Journal of Horticultural Science. 9 (3-4): 23-36.

Holb, I.J. (2004a): The brown rot fungi of fruit crops (Monilinia spp.) III. Important features of their disease control (Review). International Journal of Horticultural Science. 10 (4): 31-48.

Holb, I.J. (2004b): The brown rot fungi of fruit crops (Monilinia spp.) II. Important features of their epidemiology (Review). International Journal of Horticultural Science. 10 (1): 17-35.

Holb, I.J. \& Schnabel, G. (2005): Comparison of fungicide treatments combined with sanitation practices on brown rot blossom blight incidence, phytotoxicity, and yield for organic sour cherry production. Plant Disease. 89: 1164-1170.

Holtz, B.A., Michailides, T.J. \& Hong, C.X. (1998): Development of apothecia from stone fruit infected and stromatized by Monilinia fructicola in California. Plant Disease. 82 (12): 1375-1380.
Hong, C.X., Holtz, B.A., Morgan, D.P. \& Michailides, T.J. (1997): Significance of thinned fruit as a source of the secondary inoculum of Monilinia fructicola in California nectarine orchards. Plant Disease. 81 (5): 519-524.

Jenkins, P.T. \& Reinganum, C. (1965): The occurrence of quiescent infection of stone fruits caused by Sclerotinia fructicola (Wint.) Rehm. Australian Journal of Agricultural Research. 16: 131-140.

Jenkins, P.T. (1968): The longevity of conidia of Sclerotinia fructicola (Wint.) Rehm. under field conditions. Australian Journal of Biological Science. 21: 937-945.

Jerome, S.M.R. (1958): Brown rot of stone fruits: latent contamination in relation to spread of the disease. Journal of Australian Institute of Agricultural Science. 24: 132-140.

Kable, P.F. (1965a): Air dispersal of conidia of Monilinia fructicola in peach orchards. Australian Journal of Experimental Agriculture Animal Husbandry. 5: 172-175.

Kable, P.F. (1965b): The fruit peduncle as an important overwintering site of Monilinia fructicola in the Murrumbidgee Irrigation Areas. Australian Journal of Experimental Agriculture Animal Husbandry. 5: 172-175.

Kimura, J. (1962): Studies on the Monilia disease of the apple caused by Sclerotinia mali Takahashi. Aomori Apple Exp. Stn. Bull. 6: 1-87.

Landgraf, F.A. \& Zehr, E.I. (1982): Inoculum sources for Monilinia fructicola in South Carolina peach orchards. Phytopathology. 72: 185-190.

Larena, I. \& Melgarejo, P. (1996): Biological control of Monilinia laxa and Fusarium oxysporum f. sp. lycopersici by a lytic enzyme-producing Penicillium purpurogenum. Biological Control. 6: $361-367$.

Larena, I., De Cal, A., Linan, M. \& Melgarejo, P. (2003): Drying of Epicoccum nigrum conidia for obtaining a shelf-stable biological product against brown rot disease. Journal of Applied Microbiology. 94 (3): 508-514.

Latorre, B.A. \& Lolas M.A. (1986): Efficacy of new sterolinhibiting fungicides for the control of European brown rot. Phytopathology. 76: 1107. (Abstract)

Luo, Y., Ma, Z. \& Michailides, T.J. (2001): Analysis of factors affecting latent infection and sporulation of Monilinia fructicola on prune fruit. Plant Disease. 85: 999-1003.

Madrigal, C. \& Melgarejo, P. (1994): Mechanisms of action of the antibiotic flavipin on Monilinia laxa and Saccharomyces cerevisiae. Mycological Research. 98: 874-878.

Madrigal, C., Tadeo, J.L., \& Melgarejo, P. (1991): Relationship between flavipin production of Epicoccum nigrum and antagonism against Monilinia laxa. Mycological Research. 98: 874-878.

Melgarejo, P., Carrillo, R. \& M-Sagasta, E. (1985): Mycoflora of peach twigs and flowers and its possible significance in biological control of Monilinia laxa. Transaction for the British Mycological Society. 85: 313-317.

Melgarejo, P., Carrillo, R. \& M-Sagasta, E. (1986): Potential for biological control of Monilinia laxa in peach twigs. Crop Protection. 5: 422-426.

Michailides, T.J. \& Morgan, D.P. (1997): Influence of fruit-tofruit contact on the susceptibility of French prune to infection by Monilinia fructicola. Plant Disease. 81: 1416-1424.

Mirocha, C.J. \& Wilson. E.E. (1961): Hull rot diseases of almonds. Phytopathology. 51: 843-847. 
Mix, A.J. (1930): A blight of flowering almond, Prunus glandulosa Thunb. Phytopathology. 20: 265.

Ogawa, J.M. \& McCain, A.H. (1960): Relations of spore moisture content to spore shape and germination reaction temperature (abs.) Phytopathology. 50: 85 .

Ogawa, J.M. \& English, H. (1960): Blossom blight and green fruit rot of almond, apricot and plum caused by Botrytis cinerea. Plant Disease Reporter. 44: 265-268.

Ogawa, J.M. \& English, H. (1991): Diseases of temperate zone tree fruit and nut crops. University of California, Division of Agricultural and Natural Resources. pp. 461.

Ogawa, J.M. English, H., Moller, W.J., Manji, B.T., Rough, D. \& Koike, S.T. (1980): Brown rot of stone fruits. Calif. Univ. Div. Agric. Sci. Leaf. 2206, 7 pp.

Ogawa, J.M., Manji, B.T. \& MacSwan, I.C. (1986): Field test procedures for evaluation of fungicides for control of Monilinia laxa on stone fruits. 152-154. In: Hickey, K. D. (ed.): Methods for evaluating pesticides for control of plant pathogens. APS Press, St. Paul, USA.

Ogawa, J.M., Manji, B.T. \& Sonoda, R.M. (1985): Management of the brown rot disease on stone fruits and almonds in California. 8-15. In: Proceedings of the brown rot of stone fruit workshop, Ames. Iowa, July 11, 1983. New York State Agricultural Experimental Station Geneva Specific Report 55.

Pascual, S., Melgarejo, P. \& Magan, N. (1999): Production of the fungal biocontrol agent Epicoccum nigrum by solid substrate fermentation: effect of water activity on accumulation of compatible solutes. Mycopathologia. 146 (2): 83-89.

Pascual, S., Melgarejo, P. \& Magan, N. (2000): Accumulation of compatible solutes in Penicillium frequentans grown at reduced water activity and biocontrol of Monilinia laxa. Biocontrol Science and Technology. 10: 71-80.

Paszternák, F., Vályi, I. \& Nyéki, J. (1982): A vegyszeres kezelések hatása a Pándy meggy gyümölcskötổdésére és a monília jelentôsége üzemi ültetvényekben. Növényvédelem. 13 (9): 407-411.

Rudolph, B. A. (1925): Monilinia blossom blight (brown-rot) of apricots. California University Agricultural Experimental Station Bulletin. 383.

Schlagbauer, H.E. Holz, G. (1990): Infection and colonization of plum blossoms by Monilinia laxa. Phytophylactica. 22 : 419-422.

Sharma, R.L. \& Kaul, J.L. (1987): Blossom blight and fruit rot of apple. Indian Journal of Plant Pathology. 5:205-206.

Sholberg, P.L., Ogawa, J.M. \& Manji, B.T. (1981): Diseases of Prune blossoms, fruits, and leaves. 121-125. In: (ed.): Ramos, D. E. Prune orchard management. Univ. Calif. Div. Agric. Sci. Publ. 3269.

Soltész M. (1997): Kórokozókkal és kártevốkkel szembeni ellenállóság. 71-84. In: Soltész M. (ed.) Integrált gyümölcstermesztés. Mezốgazda Kiadó, Budapest.

Sonoda, R.M., Ogawa, J.M., Manji, B.T., Shabi, E. \& Rough, D. (1983): Factors affecting control of blossom blight in a peach orchard with low level benomyl-resistant Monilinia fructicola. Plant Disease. 67: 681-684.

Stensvand, A., Talgo, V. \& Borve, J. (2001): Seasonal production of conidia of Monilinia laxa from mummified fruits, blighted spurs and flowers of sweet cherry. Gartenbauwissenschaft. 66 (6): 273-281.

Sutton, T.B. \& Clayton, C.N. (1972): Role and survival of Monilinia fructicola in blighted peach branches. Phytopathology. 62: 1369-1373.

Szabó, Z. (1997): Kajszi. 587-599. In: Soltész, M. (ed.): Integrált gyümölcstermesztés. Mezôgazda Kiadó, Budapest.

Tamm, L., Minder, Chr. E. \& Flückinger, W. (1995): Phenological analyses of brown rot blossom blight of sweet cherry caused by Monilinia laxa. Phytopathology 85 : 401-408.

Tate, K.G. \& Corbin, J.B. (1978): Quiscent fruit infections of peach, apricot, and plum in New Zealand caused by the brown rot fungus, Sclerotinia fructicola. New Zealand Journal of Experimental Agriculture. 6: 319-325.

Tate, K.G. \& Ogawa, J.M. (1975): Nitidulid beetles as vectors of Monilinia fructicola in California stone fruits. Phytopathology. 65: 977-983.

Tilford, P.E. (1936): The relation of temperature to the effect of hydrogen and hydroxyl-ion concentration in Sclerotinia fructicola and Fomes annosus spore germination and growth. Ohio Agricultural Experimental Station Bulletin. 567: 1-27.

Véghelyi, K., Apostol, J., Jones, A. L. \& Iezzony, A. (1996): Magyar-amerikai együttmûködés a betegségellenálló meggyfajták nemesítése érdekében. Moniliniás virágszáradás és gyümölcsrothadás okozója (Monilinia laxa /Aderhold et Ruhland/ Honey és Monilinia fructicola /G. Wint./ Honey) elleni rezisztencia. Új Kertgazdaság. 2 (1): 53-58.

Wade, G.C. \& Cruickshank, R.H. (1992): The establishment and structure of latent infections with Monilinia fructicola on apricot. Journal of Phytopathology. 136: 95-106.

Wade, G.C. (1956): Investigations on brown rot of apricots caused by Sclerotinia fructicola (Wint.) Rhem. I. The occurrence of latent infection in fruit. Australian Journal of Agricultural Research. 7: 504-515.

Weaver, L.O. (1943): Effect of temperature and relative humidity on occurrence of blossom blight of stone fruit. Phytopathology. 33: 15 .

Weaver, L.O. (1950): Effect of temperature and relative humidity on occurrence of blossom blight of stone fruits. Phytopathology. 40: 1136-1153.

Wilcox, W.F. (1989): Influence of environment and inoculum density on the incidence of brown rot blossom blight of sour cherry. Phytopathology. 79: 530-534.

Willetts, H.J. \& Burllock, S. (1993): Cytology, histology and histochemistry of fruit infection by Monilinia species. In A. R. Biggs (eds.) Handbook of cytology, Histology and Histochemistry of Fruit Tree Diseases pp. 113-136. CRC Press: Boca Raton.

Willetts, H.J. \& Harada, Y. (1984): A review of apothecial production by Monilinia fungi in Japan. Mycologia. 76:314-325.

Wilson, E.E. \& Baker, G.A. (1946): Some aspects of the aerial dissemination of spores, with special reference to conidia Sclerotinia laxa. Journal of Agricultural Research. 72: 301-327.

Zehr, E.I. (1985): Importance and control of blossom blight in the southeastern United States. New York State Agricultural Experimental Station Spec. Report 55: 2-4. 